\title{
Primary Intracerebral Malignant Fibrous Histiocytoma Mimicking a Meningioma
}

\author{
Meningiom Benzeri Nadir Bir Patoloji: Primer Intraserebral Malign \\ Fibröz Histiositom
}

\author{
Mevci OZDEMIR ${ }^{1}$, Onur OZGURAL ${ }^{2}$, Melih BOZKURT ${ }^{2}$, Fuat Mehmet TORUN ${ }^{3}$, Aylin OKCU HEPER ${ }^{4}$, \\ Hakan TUNA ${ }^{2}$ \\ ${ }_{1}^{1}$ Pamukkale University, Faculty of Medicine, Department of Neurosurgery, Denizli, Turkey \\ ${ }^{2}$ Ankara University, Faculty of Medicine, Department of Neurosurgery, Ankara, Turkey \\ ${ }^{3}$ Harran University, Faculty of Medicine, Department of Neurosurgery, Sanliurfa, Turkey \\ ${ }_{4}^{4}$ Ankara University, Faculty of Medicine, Department of Pathology, Ankara, Turkey
}

Correspondence address: Mevci OZDEMIR / E-mail: drmevci@hotmail.com

\begin{abstract}
We describe herein a patient with primary intracerebral malignant fibrous histiocytoma (MFH) to demonstrate this very rare central nervous system tumor. A 42-year-old male was admitted to our institute with the complaints of headache and speech impairment. Magnetic resonance imaging (MRI) revealed a tumor consistent with meningioma and we decided the surgery. The tumor was excised totally during the initial surgery. Histopathological examination revealed a mesenchymal tumor with an invasion of the adjacent brain and underlying dura mater. On the postoperative 4th month, the follow up MRI showed tumor recurrence at the same location and of similar size. Reoperation was performed and the tumor was again removed gross totally. However, the patient demonstrated a rapidly progressive course leading to death within the first year after the surgery. Two significant points of this case of primary central nervous system MFH are the rarity of its occurrence and its mimicking a meningioma.
\end{abstract}

KEYWORDS: Brain tumor, Histiocytic disorders, Malignant fibrous histiocytoma, Meningioma

öz

Bu yazıda, çok nadir görülen primer intraserebral malign fibröz histiositom olgusu sunulmuştur. 42 yaşında erkek hasta baş ağrısı ve konuşma bozukluğu şikayeti ile kliniğimize başvurdu. Hastanın MRG incelemesinde radyolojik görünümü meningiom ile uyumlu olabilecek bir lezyonla karşılaşıldı ve cerrahi tedavi ile tümör dokusu total olarak eksize edildi. Histopatolojik incelemede dura materin altında komşu beyin parankimine invaze olmuş tümörün meningiomdan farklı agresif bir tümör olduğu anlaşıldı. Hastanın postoperatif 4. ay kontrol MRG'de aynı lokalizasyonda ve benzer boyutlarda tümör dokusu ile karşılaşıldı. Hasta tekrar opere edildi ve tümör dokusu total olarak eksize edildi. Buna rağmen hastanın kliniği hızlı bir progresyon gösterdi ve başlangıç cerrahisinden sonra 1 yıl içerisinde hayatını kaybetti. Bu yazıda bizim vurgulamak istediğimiz iki önemli nokta bulunmaktadır bunlar; santral sinir sistemi MFH'sının çok nadir ve agresif seyirli bir tümör olması ve radyolojik olarak meningiom ile karışabilmesidir.

ANAHTAR SÖZCÜKLER: Beyin tümörü, Histiositik hastalıklar, Malign fibröz histiositom, Meningiom

\section{INTRODUCTION}

The term "malignant fibrous histiocytoma" (MFH) was introduced by Ozzello et al. in 1963 (5). Malignant fibrous histiocytoma is a common soft tissue sarcoma, usually arising from the extremities and retroperitoneum. However, primary intracerebral MFH is rare, and only 33 cases of primary central nervous system (CNS) MFH have been reported (4). In this report, we present a case of primary intracerebral MFH, and the clinicopathological and radiologic characteristics are discussed.

\section{CASE REPORT}

A 42-year-old male was admitted to our institute with the complaints of headache and speech impairment. Neurologic examination showed mild motor dysphasia and mild right hemiparesis. Magnetic resonance imaging revealed a tumor in the left frontoparietal region measuring $6 \times 8 \times 5 \mathrm{~cm}$, with enhanced contrast, near the dura mater and demonstrating a dural tail, consistent with meningioma (Figure 1A, B).

The patient underwent a left frontoparietal craniotomy for tumor excision. The tumor, which was adhered to dura, was totally removed. Postoperative early stage computed tomography (CT) confirmed no residual mass lesion (Figure 2). Histopathological examination revealed a mesenchymal tumor with an invasion of the adjacent brain and underlying dura. The tumor consisted of spindle cells, forming short fascicles and occasionally a storiform pattern. Small groups of large bizarre tumor cells and foci of necrosis were 

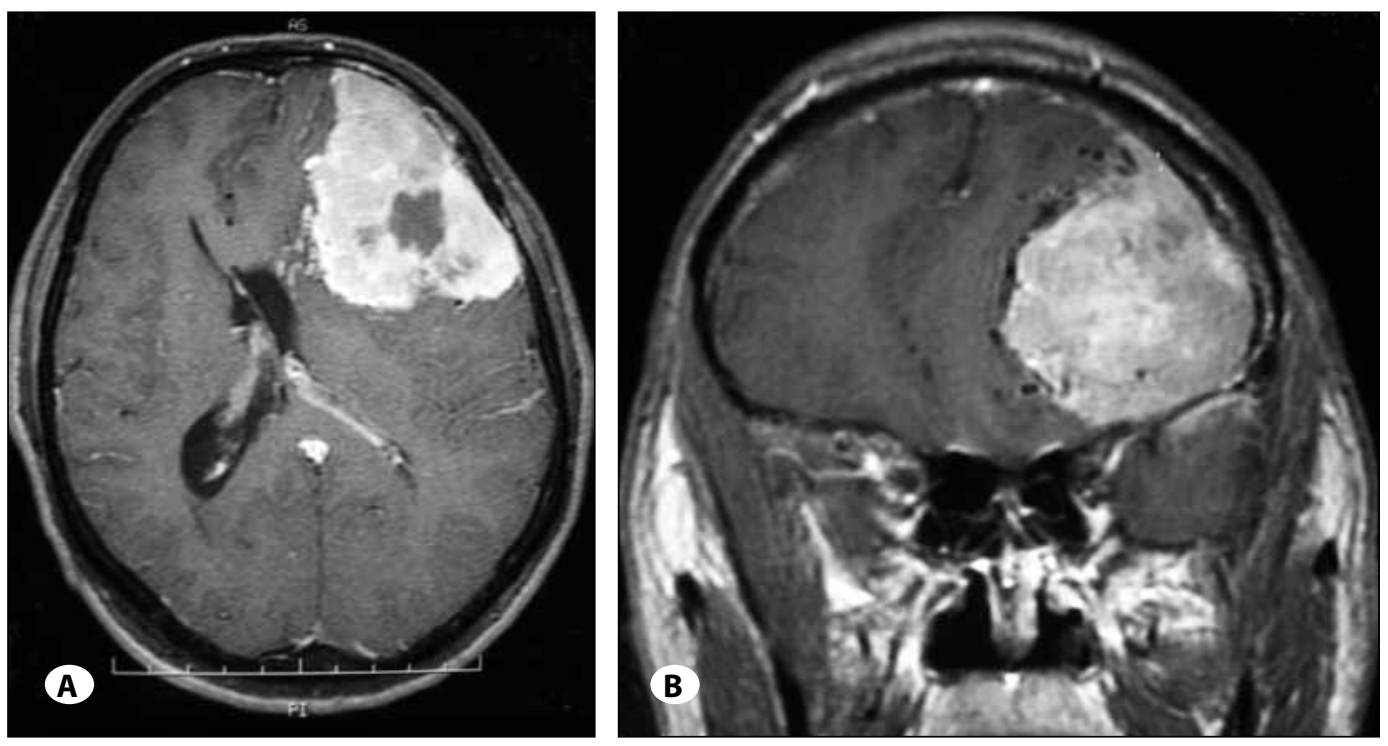

Figure 1A, B:

Preoperative MRI shows enhanced contrast and dural tail of the tumor.

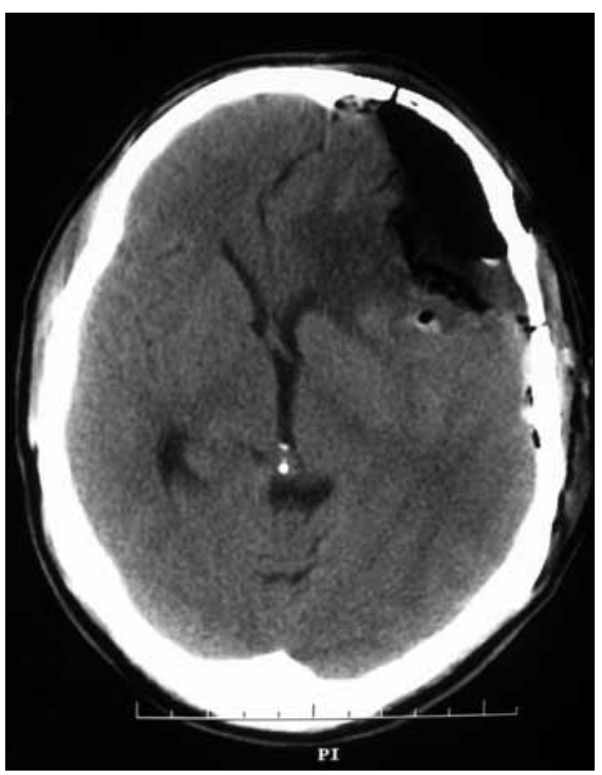

Figure 2: Postoperative early stage follow-up cranial CT.

also seen. Reticulin fibers and surrounding tumor cells were demonstrated by reticulin stain. The immunohistochemical stains showed only vimentin expression by the tumor cells. EMA, S100, GFAP and CD34 were negative. Ki-67 proliferation index was $70 \%$ (Figure $3 \mathrm{~A}, \mathrm{~B}$ ).

The patient was discharged afterseven days, and60Gyadjuvant radiotherapy and doxorubicin $50 \mathrm{mg} / \mathrm{m}^{2}$ were administered in 4 cycles as the chemotherapy protocol. Follow-up MRI on the postoperative 4th month demonstrated tumor recurrence at the same location and of similar size (Figure 4). Reoperation was performed and the only recurrent tumor mass again removed. Nevertheless, the patient underwent repetitive resections of recurrent lesions and a rapidly progressive course resulted in his death within the first year after the surgery.
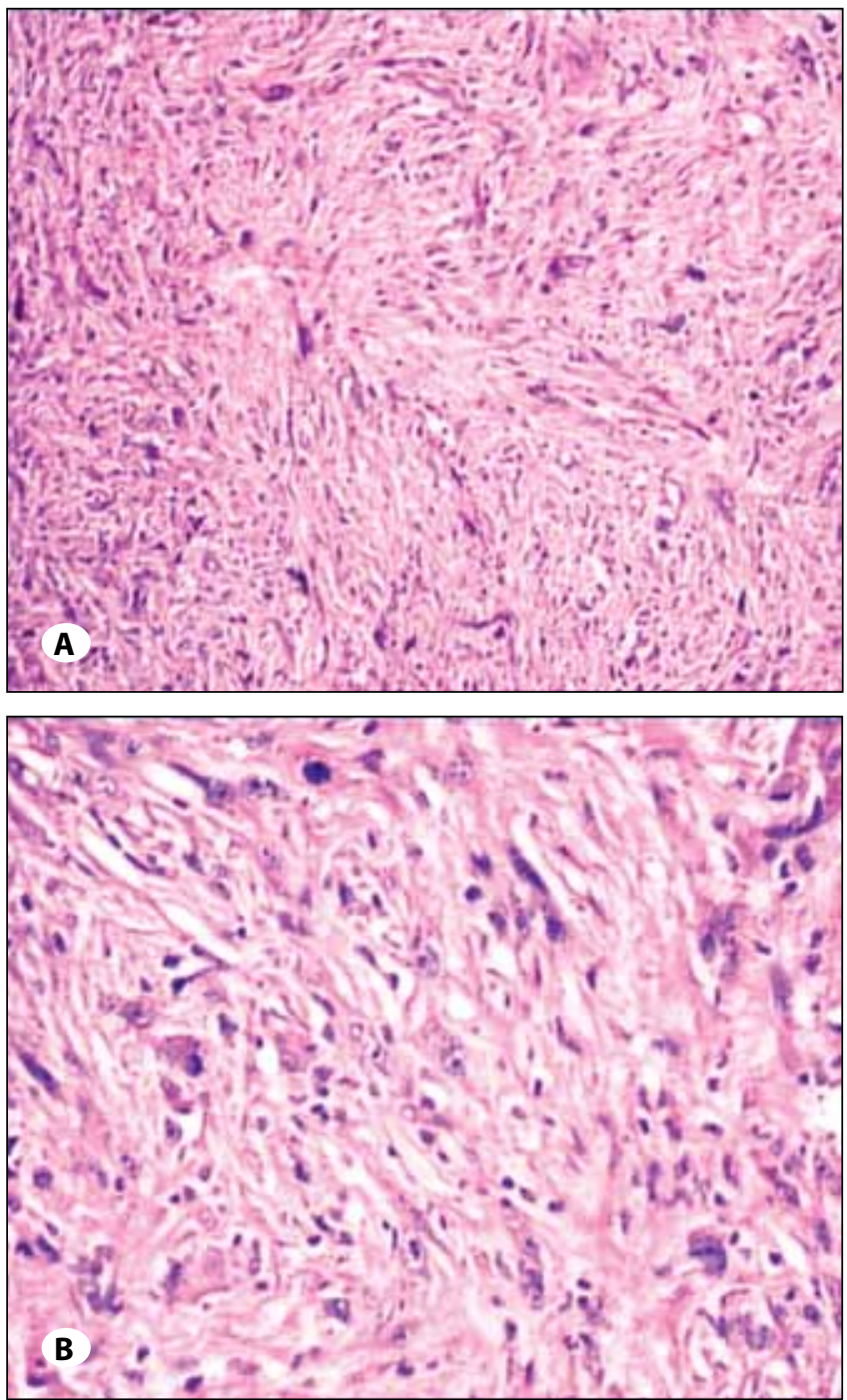

Figure 3: A) Spindle tumor cells forming storiform pattern, H\&Ex200. B) Large bizarre tumor cells, H\&Ex400. 


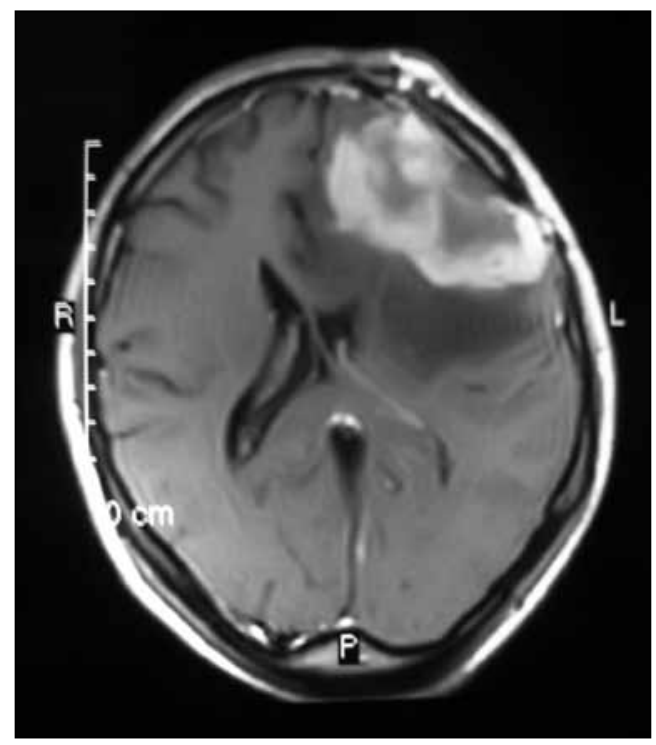

Figure 4: Postoperative follow-up MRI.

\section{DISCUSSION}

Intracerebral MFH is an extremely rare disorder, in our knowledge only 33 cases reported since 1976 (4). Primary $\mathrm{MFH}$ of the CNS generally originates from the meninges and is revealed as an extraaxial mass lesion. It is often difficult to distinguish intracerebral MFH from other neoplasms such as meningioma, gliosarcoma, schwannoma, pleomorphic xanthoastrocytoma and malignant gliomas (6). In our patient, the homogeneous contrasting, localization near the dura mater and dural tail until intraoperative visualization were considered to point to meningioma. Mitsuhashi et al. classified these cases of intracranial MFH into 3 types as: meningeal MFH arising from histiocytes or undifferentiated multipotential cells found in the meninges (18 cases); parenchymal MFH originating from perivascular or pial sheath surrounding the Virchow-Robin space (12 cases); and ventricular MFH arising from mesenchymal precursor cells of the tela choroidea (1 cases). Two cases were unclassified and the origin was unknown (4). Our case corresponds to meningeal MFH.

Malignant fibrous histiocytoma frequently recurs locally, so adequate surgical excision is the significant point for survival. It is usually resistant to chemotherapy and radiation therapy. Presumably, radical removal followed by adjuvant radiation therapy is required; chemotherapy effectiveness for intracranial MFH is undetermined $(2,3)$. Although wide resection is the treatment of choice, there are functional problems in tumors of the head that often make wide resection difficult in contrast to tumors in other regions.
Postoperative adjuvant chemotherapy and radiotherapy are therefore recommended (7). Camacho et al. suggested the use of a combination of carboplatin, 4'-epidoxorubicin and methotrexate protocol. Also many authors recommended adding $60 \mathrm{~Gy}$ local adjuvant radiotherapy to this combination $(7,8)$.

The prognosis, which was described by Berry et al, depends on the area affected, tumor size, depth of the tumor, and cell atypicality of the histopathological types; the storiform pattern has the most favorable prognosis (1).

We have reported herein a rare case of intracerebral MFH. In addition to the unusual localization of this tumor in the CNS, the other significant feature was the radiological view. Malignant fibrous histiocytoma can mimic a benign meningioma and should be monitored if the tumor size is not large. The two significant points of this case are the rarity of the occurrence of primary MFH of the CNS and its mimicking of a meningioma.

\section{REFERENCES}

1. Berry AD 3rd, Reintjes SL, Kepes JJ: Intracranial malignant fibrous histiocytoma with abscess- like tumor necrosis. Case report. J Neurosurg 69: 780-784, 1988

2. Fujimura N, Sugita $Y$, Hirohata $M$, Naohisa M, Terasaki M, Tokutmi T, Shigemori M: Primary intracerebral malignant fibrous histiocytoma in a child. Pediatr Neurosurg 37: 271-274, 2002

3. Hari JK, Azzarelli B, Caldemeyer KS: Malignant fibrous histiocytoma in a 9-year-old girl. Pediatr Neurosurg 24: 160-165, 1996

4. Mitsuhashi $T$, Watanabe $M$, Ohara $Y$, Hatashita $S$, Ueno $\mathrm{H}$ : Multifocal primary intracerebral malignant fibrous histiocytoma. Neurol Med Chir 44: 249-254, 2004

5. Ozzello L, Srour AP, Murray MR: Cultural characteristics of malignant histiocytomas and fibrous xanthomas. Cancer 16: 331-344, 1963

6. Simpson RH, Phillips Jl, Miller P, Hagen D, Anderson JE: Intracerebral malignant fibrous histiocytoma: A light and electron microscopic study with immunohistochemistry. Clin Neuropathol 5:185-189, 1986

7. Ueda R, Hayashi T, Kameyama K, Yoshida K, Kawase T: Orbital malignant fibrous histiocytoma with extension to the base of the skull. Neurol Med Chir 43: 263-266, 2003

8. Camacho FM, Moreno JC, Murga M, Proaño J, Cantillana J, Naranjo M, Martínez-Sahuquillo A, Macher G, Romero F: Malignant fibrous histiocytoma of the scalp: Multidisciplinary treatment. J Eur Acad Dermatol Venereol 13:175-182, 1999 